\title{
Neutrophil-lymphocyte Ratio and C-reactive Protein Level in Patients with Major Depressive Disorder Before and After Pharmacotherapy
}

\author{
A Adhikari, R Dikshit, S Karia, S Sonavane, N Shah, A De Sousa
}

\begin{abstract}
Background: Neutrophil-lymphocyte ratio (NLR) and C-reactive protein (CRP) level are useful biomarkers of inflammation. This study aimed to assess NLR and CRP level in patients with major depressive disorder before and after pharmacotherapy to determine whether NLR or CRP could be used as biomarkers of severity of major depression and whether there was any sex difference.

Methodology: Patients with major depression who received no pharmacotherapy 1 month prior to the study were included. Their haemoglobin, total white blood cell count, neutrophil and lymphocyte counts, NLR, and CRP levels were evaluated at baseline and 12 weeks post pharmacotherapy, as were the Montgomery Asberg Rating Scale for Depression, the Scale for Impact of Suicidality Management and Assessment and Planning of Care (SIS-MAP), and the Clinical Global Impression Scale - Severity. Results: 24 male and 26 female patients were included. At 12 weeks after pharmacotherapy, males had a higher haemoglobin level $(\mathrm{p}=0.025)$, higher total white blood cell count $(\mathrm{p}=0.018)$, and lower percentage of neutrophils $(\mathrm{p}=0.019)$ than females. There was no sex difference in NLR or CRP. From baseline to 12 weeks, males had no significant change in any blood parameter, but females had a significantly greater increase in the percentage of neutrophils $(p=0.0001)$ and decrease in the percentage of lymphocytes $(p$ $=0.012)$, resulting in a significantly increased NLR $(\mathrm{p}=0.001)$. Both males and females had significant improvement on all 3 scales $(\mathrm{p}<0.001)$. At 12 weeks, in males, the increase in NLR positively correlated with CRP as well as the Montgomery-Asberg Depression Rating Scale and the SIS-MAP, but not the Clinical Global Impression-Severity Scale. In females, the increase in NLR did not correlate with CRP or any of the scales.

Conclusion: In female patients, the NLR increased in response to antidepressant therapy while CRP remained unchanged. This indicated that inflammation has a role in the pathogenesis of major depression.
\end{abstract}

Key words: Antidepressive agents; C-reactive protein; Depression; Lymphocytes; Neutrophils

Dr Alka Adhikari, MD, Department of Psychiatry, Lokmanya Tilak Municipal Medical College, Mumbai, India

Dr Riteeka Dikshit, MD, Department of Psychiatry, Lokmanya Tilak Municipal Medical College, Mumbai, India

Dr Sagar Karia, MD, Department of Psychiatry, Lokmanya Tilak Municipal Medical College, Mumbai, India

Prof Sushma Sonavane, MD, Department of Psychiatry, Lokmanya Tilak Municipal Medical College, Mumbai, India

Prof Nilesh Shah, MD, Department of Psychiatry, Lokmanya Tilak Municipal Medical College, Mumbai, India

Dr Avinash De Sousa, DPM, Department of Psychiatry, Lokmanya Tilak Municipal Medical College, Mumbai, India

Address for correspondence: Dr Sagar Karia, Assistant Professor, Department of Psychiatry, Lokmanya Tilak Municipal Medical College, Mumbai, India. Email:karia777@yahoo.com

Submitted: 21 August 2017; Accepted: 21 March 2018

\section{Introduction}

Major depressive disorder is a common psychiatric problem that affects approximately $3 \%$ to $10 \%$ of the general population. ${ }^{1}$ Some neurobiological hypotheses have indicated a psychoneuroimmunological basis of major depression. ${ }^{2}$ Recent theories in depression aetiology have indicated that neuroinflammation plays a role in the development and maintenance of the disorder, and that the disorder itself may alter the immune system and inflammatory biomarkers. ${ }^{3}$ A number of cytokines, acutephase reactants, and neuroinflammatory substances such as interleukins, C-reactive protein (CRP), cortisol, and tumor necrosis factor-alpha have been reported to be elevated in patients with major depression..$^{4-7}$

Depression may also alter the neutrophil and leucocyte count. ${ }^{8}$ Depression is associated with reduced immunity and lymphocyte count. ${ }^{9}$ The neutrophil-lymphocyte ratio (NLR) has been reported to be a biomarker of inflammatory status in patients with major depression, ${ }^{10,11}$ schizophrenia, ${ }^{12}$ multiple sclerosis, ${ }^{13}$ Alzheimer's dementia, ${ }^{14}$ and bipolar disorder, ${ }^{15}$ as well as in drug-naïve patients with depression. ${ }^{10} \mathrm{High}$ NLR is associated with higher cardiovascular risk in patients with major depression. ${ }^{16}$ The NLR can be used to determine prognosis of patients with renal disease or cancer. ${ }^{17,18}$

Elevated CRP has been reported in patients with major depressive disorder. ${ }^{19-21}$ Elevated CRP is predictive 
of recurrence in major depression; patients with recurrence tend to have higher CRP levels. ${ }^{22}$ Elevated CRP shows a greater association with depression in men than women and correlates with higher cardiovascular morbidity and mortality. ${ }^{23}$ Elevated CRP has also been reported in geriatric depression with or without medical comorbidities. ${ }^{24}$

To the best of our knowledge, there has been no study of sex difference and the effect of antidepressant therapy on NLR and CRP in patients with major depression. This study aimed to assess NLR and CRP in patients with major depressive disorder before and after pharmacological treatment to determine whether NLR or CRP could be used as biomarkers of severity of major depression and whether there was any sex difference.

\section{Methodology}

This study was approved by the ethics committee of the Lokmanya Tilak Municipal Medical College. Written informed consent was obtained from each patient. Patients aged 20 to 60 years who presented to the outpatient clinic of the Department of Psychiatry at Lokmanya Tilak Municipal Medical College between January and March 2017 were recruited. Inclusion criteria were patients diagnosed with major depressive disorder (by a senior psychiatrist based on DSM-V) who were off-treatment for at least 1 month. This was to exclude any medication-induced effect on blood parameters. Exclusion criteria were the presence of any major comorbid psychiatric illness, autoimmune disorder, acute infection and fever, higher leucocyte count suggesting infection, HIV and tuberculosis, epilepsy, hypertension, diabetes, hepatic and renal failure, substance abuse or addiction except nicotine use, head trauma, intellectual impairment, obesity (body mass index of $>30 \mathrm{~kg} / \mathrm{m}^{2}$ ), use of medication that may affect NLR, use of steroids in the last year, cancer treated or detected in the last year, insight less than grade 4 , and suicide attempt.

A semi-structured proforma was used to collect sociodemographic data. Blood tests for haemoglobin, red blood cell count, total and differential white blood cell counts, platelet count, and CRP were performed at baseline and after 12 weeks of treatment. Blood was collected after overnight fasting (9-12 hours) from the antecubital vein using vacuum tubes. Patients were compulsorily followed up every 2 weeks for 12 weeks. They were prescribed escitalopram 5-25 mg as a part of the treatment; clonazepam 0.25-1 $\mathrm{mg}$ was prescribed in cases of insomnia.

The Montgomery-Asberg Depression Rating Scale was used to measure depression severity. It comprises 10 items rated on a Likert scale of 0 to 6 . Total score ranges from 0 to 60 . A cut-off point of $<6$ indicates normal, 7-19 mild depression, 20-34 moderate depression, and >35 severe depression. It has shown good reliability and validity across studies..$^{25,26}$

The Scale for Impact of Suicidality-Management, Assessment and Planning of Care (SIS-MAP) was used to measure suicide risk. It comprises 108 items that have been selected through expert criterion methodology. 16 experts were interviewed to report the most common indicators of suicide from their clinical experience. Both risk factors and resilience factors reported were compiled to construct the SIS-MAP. By including all aspects of the decisionmaking process of an expert clinician, the SIS-MAP intends to provide a simple, reliable way for clinicians to assess suicide risk. The SIS-MAP comprises 8 subscales of risk factors (demographics, psychological, comorbidities, family history, biological, protective factors, clinical ratings/observations, and psychosocial and environmental problems). The psychological subscale is further divided into: ideation, management of ideation, current state of suicidality, and planning. Most items require a yes or no response based on the presence or absence of the item, with 1 and 0 point assigned, respectively. It usually takes approximately 20 minutes to complete the SIS-MAP. The total score is calculated by summing the subtotals for all domains except for the protective factors domain and then subtracting the subtotal for protective factors domain. Thus, the final score represents the level of suicide risk in an individual across key life domains after taking into account the protective factors..$^{27,28}$

The Clinical Global Impression-Severity Scale was used to rate the severity of the patient's illness relative to the clinician's experience with patients with the same diagnosis. It is a 7-point scale from 1 (normal) to 7 (among the most severely ill patients). ${ }^{29}$

Statistical analyses were performed using the Graph Pad computerized software (Graph Pad, USA). All variables were abnormally distributed based on the ShapiroWilks test, and thus the Mann-Whitney $U$ test was used for analysis. Correlation was determined using the Pearson correlation coefficient. A p value of $<0.05$ was considered statistically significant.

\section{Results}

24 male and 26 female patients were included. Males and females were matched for age $(35.08 \pm 10.21$ years vs 39.27 \pm 10.15 years, $\mathrm{p}=0.134$ ), baseline score of the 3 scales, and all blood parameters except for higher total white blood cell count in males $(\mathrm{p}=0.044$, Table 1$)$.

At 12 weeks after pharmacotherapy, males had a higher haemoglobin level $(\mathrm{p}=0.025)$, higher total white blood cell count $(\mathrm{p}=0.018)$, and lower percentage of neutrophils $(p=0.019)$ than females. There was no sex difference in NLR or CRP (Table 1).

From baseline to 12 weeks, males had no significant change in any blood parameter, but females had a significantly greater increase in the percentage of neutrophils $(\mathrm{p}=0.0001)$ and decrease in the percentage of lymphocytes $(\mathrm{p}=0.012)$, resulting in a significant increased NLR $(\mathrm{p}=$ 0.001 ) [Table 1]. Both males and females had significant improvement on all 3 scales $(p<0.001$, Table 1$)$. At 12 weeks, in males, the increase in NLR positively correlated with CRP as well as the Montgomery-Asberg Depression 
Table 1. Comparison of blood parameters and depression scale scores in males and females at baseline and 12 weeks after pharmacotherapy.

\begin{tabular}{|c|c|c|c|}
\hline Parameter & Males $(n=24)$ & Females $(n=26)$ & $\begin{array}{l}\text { p value (Mann- } \\
\text { Whitney } U \text { test) }\end{array}$ \\
\hline Age, y & $35.08 \pm 10.21$ & $39.27 \pm 10.15$ & 0.134 \\
\hline Duration of illness, $\mathrm{m}$ & $17.43 \pm 26.81$ & $14.52 \pm 19.80$ & 0.476 \\
\hline \multicolumn{4}{|l|}{ Hemoglobin $(\mathrm{g} / \mathrm{dl})$} \\
\hline Baseline & $12.15 \pm 1.11$ & $11.62 \pm 1.19$ & 0.072 \\
\hline 12 weeks & $12.30 \pm 1.06$ & $11.65 \pm 0.96$ & 0.025 \\
\hline$P$ value & 0.398 & 0.808 & \\
\hline \multicolumn{4}{|c|}{ Total while blood cell count } \\
\hline Baseline & $6329.54 \pm 832.15$ & $6186.04 \pm 583.61$ & 0.044 \\
\hline 12 weeks & $6502.79 \pm 687.08$ & $6210.08 \pm 557.21$ & 0.018 \\
\hline $\mathrm{P}$ value & 0.360 & 0.264 & \\
\hline \multicolumn{4}{|l|}{ Neutrophils (\%) } \\
\hline Baseline & $62.00 \pm 8.63$ & $64.73 \pm 10.20$ & 0.174 \\
\hline 12 weeks & $63.54 \pm 9.11$ & $68.50 \pm 10.02$ & 0.019 \\
\hline $\mathrm{P}$ value & 0.072 & $<0.001$ & \\
\hline \multicolumn{4}{|l|}{ Lymphocytes (\%) } \\
\hline Baseline & $27.08 \pm 5.83$ & $28.54 \pm 14.83$ & 0.755 \\
\hline 12 weeks & $26.13 \pm 5.03$ & $27.19 \pm 14.88$ & 0.565 \\
\hline $\mathrm{P}$ value & 0.147 & 0.012 & \\
\hline \multicolumn{4}{|c|}{ Neutrophil/lymphocyte ratio } \\
\hline Baseline & $2.43 \pm 0.78$ & $2.55 \pm 0.87$ & 0.655 \\
\hline 12 weeks & $2.54 \pm 0.68$ & $2.85 \pm 0.89$ & 0.140 \\
\hline $\mathrm{P}$ value & 0.130 & 0.001 & \\
\hline \multicolumn{4}{|l|}{ Monocytes (\%) } \\
\hline Baseline & $1.29 \pm 1.7$ & $1.12 \pm 1.6$ & 0.583 \\
\hline 12 weeks & $1.25 \pm 1.51$ & $1.23 \pm 1.5$ & 0.968 \\
\hline $\mathrm{P}$ value & 0.813 & 0.632 & \\
\hline \multicolumn{4}{|l|}{ Basophils (\%) } \\
\hline Baseline & $1.38 \pm 2.53$ & $0.73 \pm 0.96$ & 0.757 \\
\hline 12 weeks & $1.67 \pm 2.14$ & $0.69 \pm 0.83$ & 0.094 \\
\hline$P$ value & 0.132 & 0.957 & \\
\hline \multicolumn{4}{|l|}{ Eosinophils (\%) } \\
\hline Baseline & $1.96 \pm 1.08$ & $2.19 \pm 1.32$ & 0.861 \\
\hline 12 weeks & $1.5 \pm 1.06$ & $2.15 \pm 1.34$ & 0.107 \\
\hline $\mathrm{P}$ value & 0.092 & 0.683 & \\
\hline \multicolumn{4}{|c|}{ C-reactive protein $(\mathrm{mg} / \mathrm{dl})$} \\
\hline Baseline & $5.64 \pm 0.77$ & $5.4 \pm 0.56$ & 0.278 \\
\hline 12 weeks & $5.74 \pm 0.65$ & $5.40 \pm 0.33$ & 0.106 \\
\hline $\mathrm{P}$ value & 0.731 & 0.818 & \\
\hline \multicolumn{4}{|c|}{ Montgomery-Asberg Depression Rating Scale score } \\
\hline Baseline & $32.04 \pm 2.51$ & $31.65 \pm 0.97$ & 0.549 \\
\hline 12 weeks & $13.88 \pm 1.75$ & $13.96 \pm 1.99$ & 0.444 \\
\hline $\mathrm{P}$ value & $<0.001$ & $<0.001$ & \\
\hline \multicolumn{4}{|c|}{$\begin{array}{l}\text { Scale for Impact of Suicidality-Management, } \\
\text { Assessment and Planning of Care score }\end{array}$} \\
\hline Baseline & $22.04 \pm 2.88$ & $21.85 \pm 2.63$ & 0.632 \\
\hline 12 weeks & $15.33 \pm 2.83$ & $15.81 \pm 2.88$ & 0.333 \\
\hline $\mathrm{P}$ value & $<0.001$ & $<0.001$ & \\
\hline \multicolumn{4}{|c|}{ Clinical Global Impression-Severity Scale score } \\
\hline Baseline & $4.71 \pm 0.55$ & $4.54 \pm 0.51$ & 0.289 \\
\hline 12 weeks & $2.83 \pm 0.637$ & $2.81 \pm 0.801$ & 0.792 \\
\hline P value & $<0.001$ & $<0.001$ & \\
\hline
\end{tabular}


Table 2. Correlation of the increase in the neutrophil/lymphocyte ratio with C-reactive protein and various depression scales.

\begin{tabular}{|lcccc|}
\hline $\begin{array}{l}\text { Neutrophil/ } \\
\text { lymphocyte } \\
\text { ratio }\end{array}$ & C-reactive protein & $\begin{array}{c}\text { Montgomery- } \\
\text { Asberg Depression } \\
\text { Rating Scale }\end{array}$ & $\begin{array}{c}\text { Scale for Impact } \\
\text { of Suicidality- } \\
\text { Management, } \\
\text { Assessment and } \\
\text { Planning of Care }\end{array}$ & $\begin{array}{c}\text { Clinical Global } \\
\text { Impression-Severity } \\
\text { Scale }\end{array}$ \\
Males (n-24) & & & & \\
Baseline & $r=-0.076(\mathrm{p}=0.724)$ & $r=-0.140(\mathrm{p}=0.513)$ & $r=0.069(\mathrm{p}=0.750)$ & $r=-0.247(\mathrm{p}=0.245)$ \\
12 weeks & $r=-0.454(\mathrm{p}=0.026)$ & $r=-0.570(\mathrm{p}=0.004)$ & $r=-0.053(\mathrm{p}=0.805)$ & $r=-0.296(\mathrm{p}=0.160)$ \\
\hline $\begin{array}{l}\text { Females (n=26) } \\
\text { Baseline }\end{array}$ & $r=0.166(\mathrm{p}=0.438)$ & $r=-0.206(\mathrm{p}=0.323)$ & $r=-0.123(\mathrm{p}=0.558)$ & $r=-0.304(\mathrm{p}=0.140)$ \\
12 weeks & $r=0.007(\mathrm{p}=0.974)$ & $r=-0.020(\mathrm{p}=0.923)$ & $r=-0.131(\mathrm{p}=0.532)$ & $r=-0.240(\mathrm{p}=0.248)$ \\
\hline
\end{tabular}

Rating Scale and the SIS-MAP, but not the Clinical Global Impression-Severity Scale. In females, the increase in NLR did not correlate with CRP or any of the scales (Table 2).

\section{Discussion}

The immune system may change with depression and an inflammatory response may be triggered in depression. ${ }^{30}$ Nonetheless, not all patients with major depressive disorder demonstrate a change in the immune system secondary to inflammation. In our study, only female patients showed a significant increase in NLR after 12 weeks of pharmacotherapy. Many confounding factors such as psychosocial variables, substance use, nicotine dependence, comorbid psychiatric disorders, marital and interpersonal problems, and antidepressant treatment may affect the immune response.$^{31}$ Antidepressants may affect the lymphocyte response to inflammation in depressed patients. ${ }^{32}$ It may be challenging to assess these responses in patients with depression, and the NLR may be a better indicator of immune function and response to treatment.

Multiple pro-inflammatory cytokines may affect the immune system and alter the white blood cell count. In our study, CRP did not increase significantly after treatment. We did not measure interleukin-6 or interleukin- 1 that have been implicated to have a direct role in the pathophysiology of depression ${ }^{33}$ and affect the serotonin neurotransmitter system by decreasing serotonin synthesis from tryptophan and activating alternate toxic metabolites of tryptophan. ${ }^{34}$ A decreased lymphocyte response and neutrophil activity have been implicated in depression in response to cytokines along with hormonal changes via desensitization of cortisol receptors altering the stress response via the hypothalamopituitary-adrenal axis. ${ }^{35,36}$

In our study, the NLR did not differ between sexes at baseline or at 12 weeks after treatment. Only females showed a significant increase in NLR after treatment, in keeping with increased neutrophil and decreased lymphocyte percentages. We hypothesize that females had a greater inflammatory response than males. This finding is in contrast to a theory that decreased NLR occurs with response to treatment. ${ }^{37}$ Increased NLR and neutrophil percentage may indicate a better immune response following 12 weeks of treatment. An increased NLR is a poor prognostic factor for cancer and acute myocardial infarction. An increased NLR may indicate that females show an inflammatory pattern in depression and may serve as a marker of depression with poorer prognosis.

In our study, in males, NLR was positively correlated with the Montgomery-Asberg Depression Rating Scale and SIS-MAP but not the Clinical Global Impression-Severity Scale. This indicates that increased NLR is associated with reduced depressive symptoms and suicide risk. Increased NLR also correlated with increased CRP indicating an inflammatory process at play. It is prudent to conclude that depression affects the immune response and white blood cell count irrespective of severity. In females, the increase in NLR did not correlate with CRP or any of the scales.

Our study had several limitations. Only out-patients were included; the sample size was small $(\mathrm{n}=50)$; and depression subgroups were not categorised into acute or chronic. In addition, subtypes of lymphocytes were not evaluated, and there was no analysis of cytokines in combination with NLR. Only one antidepressant (escitalopram) was used; it is unknown if the increase in NLR is related to a direct drug effect or a result of improved depressive state.

\section{Conclusion}

In female patients, the NLR increased in response to antidepressant therapy while CRP remained unchanged. This 
indicated that inflammation has a role in the pathogenesis of major depression. Further research is warranted to ascertain whether the NLR is a useful marker for major depression and its response to treatment.

\section{Acknowledgement}

We thank the Department of Pathology, Lokmanya Tilak Municipal Medical College.

\section{Declaration}

The authors have no conflicts of interest to disclose.

\section{References}

1. Muñoz RF, Cuijpers P, Smit F, Barrera AZ, Leykin Y. Prevention of major depression. Annu Rev Clin Psychol 2010;6:181-212. cross ret

2. Jaremka LM, Lindgren ME, Kiecolt-Glaser JK. Synergistic relationships among stress, depression, and troubled relationships: insights from psychoneuroimmunology. Depress Anxiety 2013;30:28896. Eross ret

3. Hurley LL, Tizabi Y. Neuroinflammation, neurodegeneration, and depression. Neurotox Res 2013;23:131-44. Eross re

4. Dowlati Y, Herrmann N, Swardfager W, Liu H, Sham L, Reim EK, et al. A meta-analysis of cytokines in major depression. Biol Psychiatry 2010;67:446-57. cross ret

5. Herbert J. Cortisol and depression: three questions for psychiatry. Psychol Med 2013;43:449-69. Eross re

6. Wium-Andersen MK, Ørsted DD, Nielsen SF, Nordestgaard BG. Elevated C-reactive protein levels, psychological distress, and depression in 73,131 individuals. JAMA Psychiatry 2013;70:17684. Eross ret

7. Bob P, Raboch J, Maes M, Susta M, Pavlat J, Jasova D, et al. Depression, traumatic stress and interleukin-6. J Affect Disord 2010;120:2314. Eross res

8. Duggal NA, Upton J, Phillips AC, Hampson P, Lord JM. Depressive symptoms are associated with reduced neutrophil function in hip fracture patients. Brain Behav Immun 2013;33:173-82. Eross ref

9. Miller AH. Depression and immunity: a role for T cells? Brain Behav Immun 2010;24:1-8. Eross re

10. Demir S, Atli A, Bulut M, İbiloğlu AO, Güneş M, Kaya MC, et al. Neutrophil-lymphocyte ratio in patients with major depressive disorder undergoing no pharmacological therapy. Neuropsychiatr Dis Treat 2015;11:2253-8.

11. Zorrilla EP, Luborsky L, McKay JR, Rosenthal R, Houldin A, Tax A, et al. The relationship of depression and stressors to immunological assays: a meta-analytic review. Brain Behav Immun 2001;15:199226. Eross re

12. Semiz M, Yildirim O, Canan F, Demir S, Hasbek E, Tuman TC, et al. Elevated neutrophil/lymphocyte ratio in patients with schizophrenia. Psychiatr Danub 2014;26:220-5.

13. Demirci S, Demirci S, Kutluhan S, Koyuncuoglu HR, Yurekli VA. The clinical significance of the neutrophil-to-lymphocyte ratio in multiple sclerosis. Int J Neurosci 2016;126:700-6.

14. Kuyumcu ME, Yesil Y, Oztürk ZA, Kizilarslanoğlu C, Etgül S, Halil $\mathrm{M}$, et al. The evaluation of neutrophil-lymphocyte ratio in Alzheimer's disease. Dement Geriatr Cogn Disord 2012;34:69-74. Eross re

15. Kalelioglu T, Akkus M, Karamustafalioglu N, Genc A, Genc ES, Cansiz A, et al. Neutrophil-lymphocyte and platelet-lymphocyte ratios as inflammation markers for bipolar disorder. Psychiatry Res 2015;228:925-7. cross ret

16. Meissner J, Irfan A, Twerenbold R, Mueller S, Reiter M, Haaf P, et al. Use of neutrophil count in early diagnosis and risk stratification of AMI. Am J Med 2011;124:534-42. Eross re
17. Turkmen K, Guney I, Yerlikaya FH, Tonbul HZ. The relationship between neutrophil-to-lymphocyte ratio and inflammation in end-stage renal disease patients. Ren Fail 2012;34:155-9. Eross re

18. Guthrie GJ, Charles KA, Roxburgh CS, Horgan PG, McMillan DC, Clarke SJ. The systemic inflammation-based neutrophil-lymphocyte ratio: experience in patients with cancer. Crit Rev Oncol Hematol 2013;88:218-30. cross re

19. Pasco JA, Nicholson GC, Williams LJ, Jacka FN, Henry MJ, Kotowicz MA, et al. Association of high-sensitivity C-reactive protein with de novo major depression. Br J Psychiatry 2010;197:372-7. cross re

20. Khandaker GM, Pearson RM, Zammit S, Lewis G, Jones PB. Association of serum interleukin 6 and C-reactive protein in childhood with depression and psychosis in young adult life: a population-based longitudinal study. JAMA Psychiatry 2014;71:1121-8. Eross re

21. Hiles SA, Baker AL, De Malmanche T, Attia J. Interleukin-6, Creactive protein and interleukin-10 after antidepressant treatment in people with depression: a meta-analysis. Psychol Med 2012;42:201526. cross re

22. Copeland WE, Shanahan L, Worthman C, Angold A, Costello EJ. Cumulative depression episodes predict later C-reactive protein levels: a prospective analysis. Biol Psychiatry 2012;71:15-21. Eross re

23. Deverts DJ, Cohen S, DiLillo VG, Lewis CE, Kiefe C, Whooley M, et al. Depressive symptoms, race, and circulating C-reactive protein: the Coronary Artery Risk Development in Young Adults (CARDIA) study. Psychosom Med 2010;72:734-41. cross re

24. Palta P, Xue QL, Deal JA, Fried LP, Walston JD, Carlson MC. Interleukin-6 and C-reactive protein levels and 9-year cognitive decline in community-dwelling older women: the Women's Health and Aging Study II. J Gerontol A Biol Sci Med Sci 2015;70:873-8. cross re

25. Bondolfi G, Jermann F, Rouget BW, Gex-Fabry M, McQuillan A, Dupont-Willemin A, et al. Self- and clinician-rated MontgomeryÅsberg Depression Rating Scale: evaluation in clinical practice. J Affect Disord 2010;121:268-72. Eross re

26. Kjaergaard M, Arfwedson Wang CE, Waterloo K, Jorde R. A study of the psychometric properties of the Beck Depression Inventory-II, the Montgomery and Åsberg Depression Rating Scale, and the Hospital Anxiety and Depression Scale in a sample from a healthy population. Scand J Psychol 2014;55:83-9. Eross re

27. Johnston ME, Nelson C, Shrivastava A. Dimensions of suicidality: analyzing the domains of the SIS-MAP Suicide Risk Assessment instrument and the development of a brief screener. Arch Suicide Res 2013; 17:212-22. Eross re

28. Shrivastava A, Johnston M, Nelson C, Lester D. Predicting suicidality among psychiatric patients. Psychol Rep 2011;109:367-8. Eross re

29. Guy W. ECDEU assessment manual for psychopharmacology. US Department of Health, Education, and Welfare, Public Health Service, Alcohol, Drug Abuse, and Mental Health Administration, National Institute of Mental Health, Psychopharmacology Research Branch, Division of Extramural Research Programs; 1976.

30. Janssen DG, Caniato RN, Verster JC, Baune BT. A psychoneuroimmunological review on cytokines involved in antidepressant treatment response. Hum Psychopharmacol 2010;25:201-15. Eross re

31. Matthews KA, Gallo LC, Taylor SE. Are psychosocial factors mediators of socioeconomic status and health connections? A progress report and blueprint for the future. Ann N Y Acad Sci 2010;1186:14673. Eross ret

32. Maes M. Depression is an inflammatory disease, but cell-mediated immune activation is the key component of depression. Prog Neuropsychopharmacol Biol Psychiatry 2011;35:664-75. Eross re

33. Valkanova V, Ebmeier KP, Allan CL. CRP, IL-6 and depression: a systematic review and meta-analysis of longitudinal studies. J Affect Disord 2013;150:736-44. cross ret

34. Dantzer R, O’Connor JC, Lawson MA, Kelley KW. Inflammationassociated depression: from serotonin to kynurenine. Psychoneuroendocrinology 2011;36:426-36. cross re

35. Lamers F, Vogelzangs N, Merikangas KR, de Jonge P, Beekman AT, Penninx BW. Evidence for a differential role of HPA-axis function, 
inflammation and metabolic syndrome in melancholic versus atypical depression. Mol Psychiatry 2013;18:692-9. cross ret

36. Krishnadas R, Cavanagh J. Depression: an inflammatory illness? J Neurol Neurosurg Psychiatry 2012;83:495-502. Eross re
37. Aydin Sunbul E, Sunbul M, Yanartas O, Cengiz F, Bozbay M, Sari I, et al. Increased neutrophil/lymphocyte ratio in patients with depression is correlated with the severity of depression and cardiovascular risk factors. Psychiatry Investig 2016;13:121-6. Eross re 